\title{
Population Dynamics of Amrasca biguttula biguttula on Bt and Non Bt Cotton and its Correlation with Abiotic Factors
}

\author{
Praveen Kumar*, S.P. Yadav, Krishna Rolania, Sunita Yadav, \\ Surender Singh and Vikas
}

Department of Entomology, CCS Haryana Agricultural University, Hisar-125004, India

*Corresponding author

\section{A B S T R A C T}

\begin{tabular}{|l|}
\hline K e y w o r d s \\
$\begin{array}{l}\text { Population dynamics, } \\
\text { Leafhopper, Abiotic } \\
\text { factors, } B t \text { cotton, } \\
\text { Correlation, Regression }\end{array}$ \\
\hline Article Info \\
\hline $\begin{array}{l}\text { Accepted: } \\
\text { 20 August } 2018 \\
\text { Available Online: } \\
\text { 10 September } 2018\end{array}$ \\
\hline
\end{tabular}

The research was conducted during kharif 2016 at CCSHAU, Hisar. Transgenic cotton RCH 650 BGII and variety H 1098 i was evaluated for their reaction to cotton leafhopper under unsprayed condition. Observations on cotton leafhopper were recorded at weekly intervals. The highest population of leafhopper was recorded during $33^{\text {rd }}$ standard week on RCH 650 BG II and $32^{\text {nd }}$ standard week on H 1098 i. Leafhopper population were significantly and positively correlated with relative humidity while negatively correlated with temperature on both RCH 650 BG II and H 1098 i. Multiple regression analysis indicated that morning relative humidity alone accounted for 39 per cent variability in leafhopper population on $\mathrm{RCH} 650 \mathrm{BGII}$ and 40 per cent variability in leafhopper population on $\mathrm{H} 1098 \mathrm{i}$, while evening relative humidity accounted for 34 per cent variability in leafhopper population on $\mathrm{RCH} 650$ BGII and 37 per cent variability in leafhopper population on H 1098 i. Minimum temperature, wind speed, rainfall and number of rainy days influenced very less $(<16 \%)$ on leafhopper population.

\section{Introduction}

Cotton (Gossypium spp.) is a major commercial crop unanimously designated as "King of Fibres" and has a global significance which is grown for its lint and seed. India is the only country where all four cultivated species (G. hirsutum, G. barbadense, $G$. arboretum and $G$. herbaceum) of cotton are grown on commercial scale. In India, cotton is cultivated in an area of $12.65 \mathrm{~m}$ ha with a production of 37.39 million bales (170 $\mathrm{kg} / \mathrm{bale}$ ) of seed cotton during 2015-16. In Haryana, total area under cotton is 6.39 lakh ha and production is 22.00 lakh bales of 170 $\mathrm{kg}$ with productivity $665 \mathrm{~kg}$ per ha (Anonymous, 2015). There are a number of causes responsible for low yield of cotton but losses caused by insect-pests are of prime importance. In India 162 insect-pests of cotton have been recorded (Dhaliwal et al., 2008). After introduction of $B t$ cotton sucking pests like leafhopper (Amrasca biguttula biguttula), aphid (Aphis gossypii), thrips (Thrips tabaci) and whiteflies (Bemisia tabaci) etc, are responsible for the major threat and destruction of cotton crop (Gahukar, 1997). Sap feeders have been reported to cause loss in the yield to extent of $8.45 \mathrm{q} / \mathrm{ha}$ in hirsutum cotton (Radhika et al., 2006). The losses in 
yield due to this pest have been reported to be 18 to 24 per cent (Bhat et al., 1986; Dhawan et al., 1988; Javed et al., 1992; Grover and Pental, 2003).

Leafhopper has become very serious pest in recent years. Thus, it now becomes very necessary to find out the optimal conditions for high population density for taking timely control measures. For developing weather based pest forecasting system, information regarding population dynamics of pest in relation to prevalent weather parameters is required. Keeping the above facts in view, the present investigation was undertaken to study the population dynamics of cotton leafhopper.

\section{Materials and Methods}

For studying the population dynamics of cotton leafhopper, transgenic cotton RCH 650 BGII and variety $\mathrm{H} 1098 \mathrm{i}$ was sown in an area of $180 \mathrm{~m}^{2}$ each on 15th may, 2016 at RRS Samargopalpur, Rohtak (Haryana). Observations on population dynamics of nymphs of A. biguttula biguttula was recorded throughout the crop season starting from first week of June, 2016 at weekly interval. Leafhopper nymphs were counted on three leaves (upper, middle and lower) on randomly selected thirty plants of each on $B t$ (RCH 650 BGII) and non $B t$ (H 1098 i) till harvesting of crop. The leafhopper population was averaged and expressed as number of nymphs per leaf. The data on weather parameters viz. temperature (maximum and minimum), relative humidity (morning and evening), rainfall, wind speed and rainy days were obtained from Indian Meteorological Department, Pune. The population of leafhopper was correlated with different weather parameter. Correlations of leafhopper population with weather parameters had been presented separately for $B t$ and non- $B t$ cotton. The association between A. biguttula biguttula population and different weather parameter was explained by linear regression models in both cultivars.

\section{Results and Discussion}

It is evident from the Table 1 that the leafhopper population initially recorded on $23^{\text {rd }}$ standard week (SW) on $B t$-cotton, $\mathrm{RCH}$ 650 BGII and non-Bt, H 1098 i during 2016. Bt Cotton, RCH 650 BGII harboured higher leafhopper population from $32^{\text {nd }}$ standard week to $34^{\text {th }}$ standard week. The highest population (2.26 nymphs per leaf) was observed on $33^{\text {rd }} \mathrm{SW}$ while lowest population (0.08 nymphs per leaf) was found on $24^{\text {th }} \mathrm{SW}$ on $B t$ cotton, RCH 650 BGII. On non- $B t$ cotton, H 1098 i higher population was observed from $30^{\text {th }}$ standard week to $33^{\text {rd }}$ standard week with peak population (1.89 nymphs per leaf) on $32^{\text {nd }} \mathrm{SW}$ and lowest population (0.02 nymphs per leaf) on $23^{\text {rd }} \mathrm{SW}$. The population remained below one nymph per leaf during the $23^{\text {rd }}$ to $29^{\text {th }} \mathrm{SW}$ and $35^{\text {th }}$ to $38^{\text {th }} \mathrm{SW}$ on $B t$ cotton, RCH 650 BGII and non-Bt cotton, H 1098 i. Correlations of leafhopper population with weather parameters have been presented separately for $B t$ and non- $B t$ cotton (Table 2). Maximum temperature had significant and negative correlation $(\mathrm{r}=-0.580)$ with leafhopper population on $B t$ cotton RCH 650 BGII whereas it showed negative and nonsignificant correlation $(\mathrm{r}=-0.487)$ on non- $B t$ cotton H 1098 i. Morning relative humidity showed highly significant and positive correlation with leafhopper population on both $B t$ RCH 650 BGII $(\mathrm{r}=0.623)$ and non- $B t \mathrm{H}$ $1098 \mathrm{i}(\mathrm{r}=0.631)$. Evening relative humidity also had significant positive correlation with leafhopper population. Minimum temperature, wind speed and rainfall showed negative and non-significant correlation on $B t$ and non-Bt. Whereas, rainy days had positive and nonsignificant correlation on both the $B t \mathrm{RCH} 650$ BGII ( $\mathrm{r}=0.155)$ and non-Bt cotton H $1098 \mathrm{i}(\mathrm{r}$ $=0.306)($ Fig. 1 and 2). 
Table.1 Population dynamics of cotton leafhopper, A. biguttula biguttula on cotton hybrids at Rohtak, Haryana during 2015-16

\begin{tabular}{|c|c|c|c|c|c|c|c|c|c|}
\hline \multirow{3}{*}{$\begin{array}{l}\text { Standard } \\
\text { weeks }\end{array}$} & \multicolumn{7}{|c|}{ Weather parameters } & \multirow{2}{*}{\multicolumn{2}{|c|}{$\begin{array}{c}\text { A verage no. } \\
\text { of } \\
\text { nymphs/leaf } \\
\text { Cotton } \\
\text { hybrid }\end{array}$}} \\
\hline & \multicolumn{2}{|c|}{ Temperature $\left({ }^{\circ} \mathrm{C}\right)$} & \multicolumn{2}{|c|}{$\begin{array}{c}\text { Relative humidity } \\
(\%)\end{array}$} & \multirow{2}{*}{$\begin{array}{c}\text { Wind } \\
\text { speed } \\
(\mathbf{k m} / \mathbf{h})\end{array}$} & \multirow[t]{2}{*}{$\begin{array}{l}\text { Rainfall } \\
\text { (mm) }\end{array}$} & \multirow[t]{2}{*}{$\begin{array}{l}\text { Rainy } \\
\text { days }\end{array}$} & & \\
\hline & Maximum & Minimum & Morning & Evening & & & & $\begin{array}{c}\text { RCH } \\
650 \\
\text { BG } \\
\text { II }\end{array}$ & $\begin{array}{c}\text { H } \\
1098 \\
\text { i }\end{array}$ \\
\hline 23 & 42.28 & 29.18 & 43.20 & 40.60 & 6.00 & 0.00 & 0 & 0.14 & 0.02 \\
\hline 24 & 40.71 & 27.46 & 49.00 & 44.14 & 7.71 & 1.14 & 3 & 0.08 & 0.06 \\
\hline 25 & 38.09 & 28.27 & 55.00 & 45.71 & 8.14 & 0.86 & 2 & 0.42 & 0.45 \\
\hline 26 & 38.49 & 29.06 & 60.29 & 52.29 & 7.29 & 0.00 & 0 & 0.43 & 0.68 \\
\hline 27 & 36.72 & 27.86 & 72.11 & 65.44 & 6.67 & 4.44 & 2 & 0.23 & 0.53 \\
\hline 28 & 36.93 & 28.27 & 86.14 & 63.57 & 6.00 & 3.29 & 4 & 0.40 & 0.53 \\
\hline 29 & 32.93 & 28.13 & 82.71 & 73.00 & 7.86 & 13.43 & 5 & 0.48 & 0.38 \\
\hline 30 & 36.43 & 27.80 & 84.43 & 63.29 & 6.71 & 3.00 & 5 & 1.79 & 1.82 \\
\hline 31 & 33.57 & 28.16 & 85.43 & 76.14 & 6.14 & 2.14 & 2 & 1.55 & 1.58 \\
\hline 32 & 35.56 & 27.64 & 84.43 & 72.29 & 6.29 & 0.29 & 2 & 2.19 & 1.89 \\
\hline 33 & 32.99 & 26.69 & 81.86 & 71.71 & 5.43 & 0.86 & 3 & 2.26 & 1.81 \\
\hline 34 & 33.71 & 27.26 & 81.71 & 66.14 & 5.43 & 0.14 & 1 & 2.02 & 1.12 \\
\hline 35 & 33.90 & 26.93 & 83.86 & 72.57 & 4.86 & 3.29 & 2 & 0.90 & 0.78 \\
\hline 36 & 33.37 & 24.84 & 83.71 & 74.71 & 9.86 & 2.14 & 1 & 0.82 & 0.60 \\
\hline 37 & 34.93 & 25.27 & 71.86 & 54.14 & 7.29 & 0.00 & 0 & 0.83 & 0.48 \\
\hline 38 & 35.01 & 25.85 & 73.57 & 57.34 & 6.32 & 0.00 & 0 & 0.68 & 0.30 \\
\hline
\end{tabular}

\section{Table.2 Correlation of $A$. biguttula biguttula population with weather parameters}

\begin{tabular}{|l|l|l|}
\hline Weather parameters & RCH 650 BGII & H 1098 i \\
\hline Maximum temperature $\left({ }^{\circ} \mathrm{C}\right)$ & $-0.580^{*}$ & -0.487 \\
\hline Minimum temperature $\left({ }^{\circ} \mathrm{C}\right)$ & -0.208 & -0.011 \\
\hline Morning relative humidity $(\%)$ & $0.623^{* *}$ & $0.631^{* *}$ \\
\hline Evening relative humidity $(\%)$ & $0.585^{*}$ & $0.611^{*}$ \\
\hline Wind speed $(\mathrm{Km} / \mathrm{h})$ & -0.401 & -0.359 \\
\hline Rainfall $(\mathbf{m m})$ & -0.207 & -0.124 \\
\hline Rainy days $($ days) & 0.155 & 0.306 \\
\hline * Indicate significant at $\mathbf{p = 0 . 0 5}$ & & \\
\hline **Indicate significant at $\mathbf{p}=\mathbf{0 . 0 1}$ & & \\
\hline
\end{tabular}




\begin{tabular}{|l|c|c|c|c|}
\hline \multicolumn{2}{|c|}{ Table.3 Regression models for A. biguttula biguttula incidence (y) in relation to } \\
Weather parameters $(\mathrm{x})$
\end{tabular}

Fig.1 Population dynamics of cotton leafhopper, A. biguttula biguttula in relation to weather parameters on $\mathrm{H} 1098 \mathrm{i}$

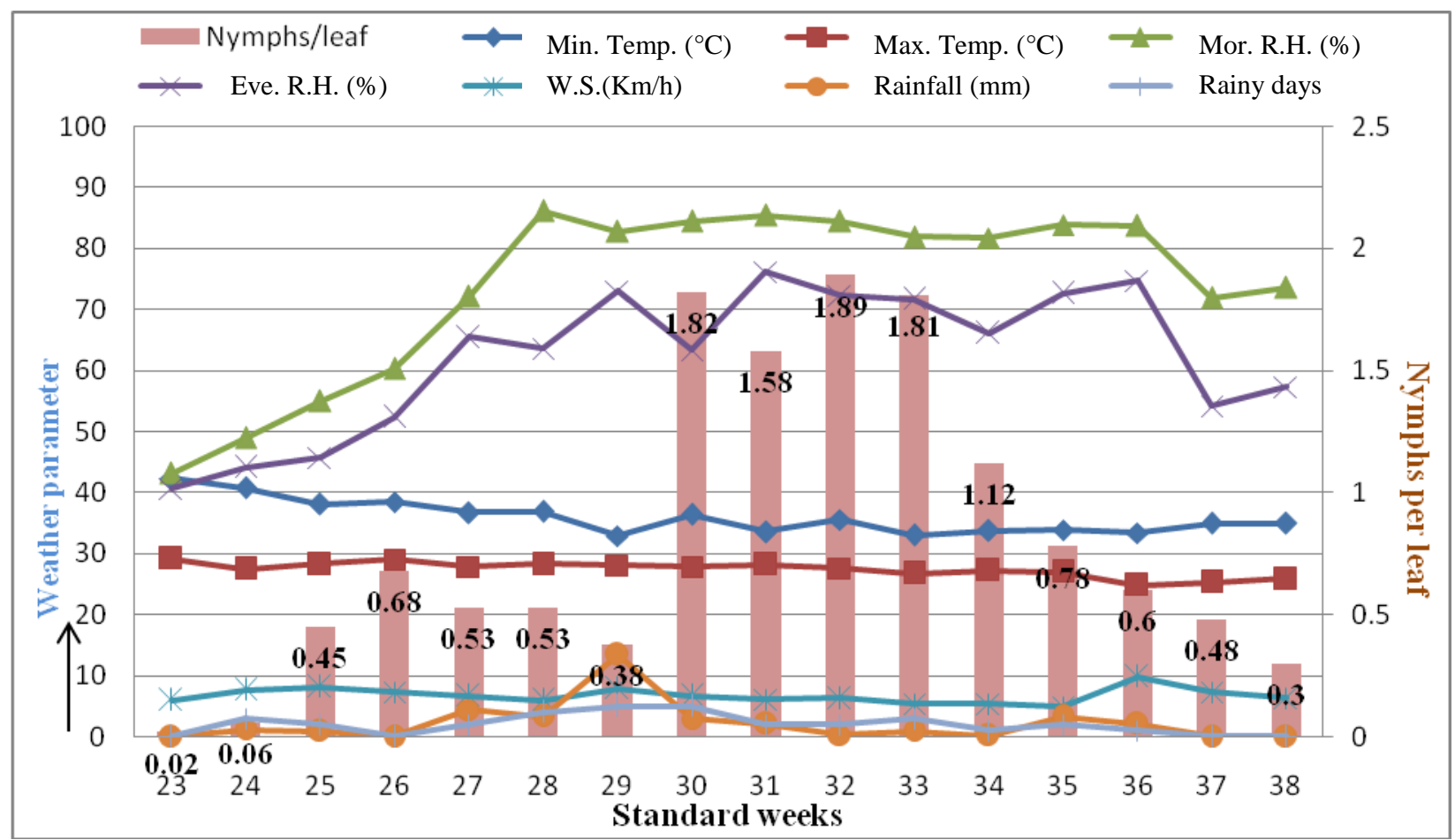


Fig.2 Population dynamics of cotton leafhopper, A. biguttula biguttula in relation to weather parameters on RCH 650 BGII

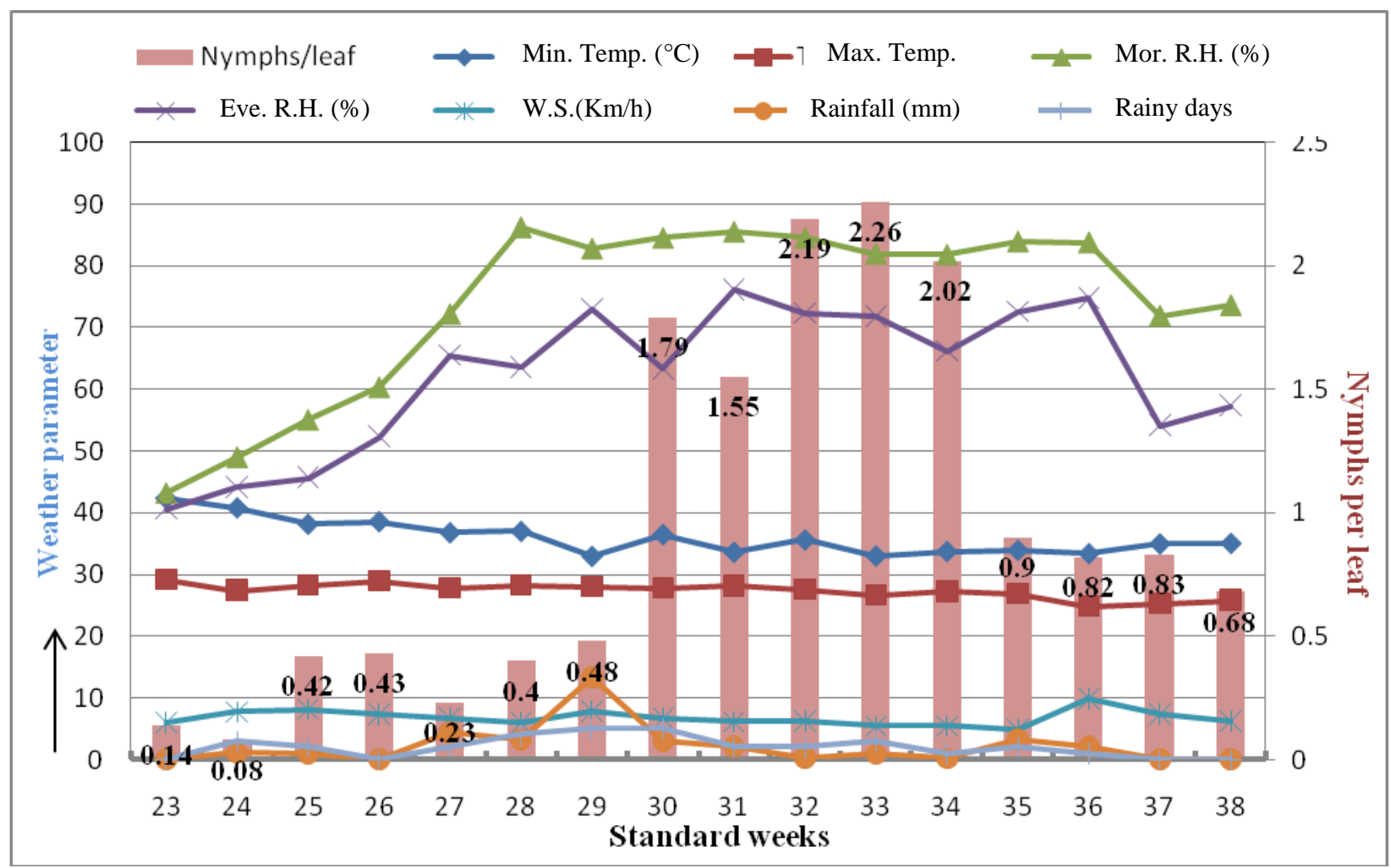

The association between A. biguttula biguttula population and different weather parameter was explained by linear regression models in both cultivars (Table 3 ).

The multiple regression analysis, which explained the average relationship between $A$. biguttula biguttula and weather parameter i.e. the amount of changes in A. biguttula biguttula population per unit change in weather parameters, indicated that morning relative humidity alone accounted for 39 per cent variability in leafhopper population on RCH 650 BGII and 40 per cent variability in leafhopper population on $\mathrm{H} 1098$ i, while evening relative humidity accounted for 34 per cent variability in leafhopper population on RCH 650 BGII and 37 per cent variability in leafhopper population on $\mathrm{H} 1098 \mathrm{i}$. Maximum temperature accounted for 34 per cent variability in leafhopper population on
RCH 650 BGII and 24 per cent variability in leafhopper population on $\mathrm{H} 1098 \mathrm{i}$. Minimum temperature, wind speed, rainfall and number of rainy days were found having very less influence $(<16 \%)$ on leafhopper population except wind speed (16\%) on RCH 650 BG II.

In the present work, average number of nymphs of cotton leafhopper, A. biguttula biguttula per leaf were found more on $B t$ cotton hybrid RCH 650 BG II as compared to non-Bt hybrid, H 1098 i. Ashfaq et al., (2010) also found maximum population of the jassid on transgenic cotton genotypes ( $\mathrm{VH}-255$ and I-2086) and the lowest population on nontransgenic genotype CIM-496 (control).

The studies were in accordance with that of Dahiya et al., (2013) who reported that the highest population of leafhopper was recorded on $B t$ genotypes. 
The initial appearance of leafhopper population in the present study was noticed in $23^{\text {rd }}$ standard week (June) and peak population of leafhopper was in $32^{\text {nd }}$ and $33^{\text {rd }}$ standard week (August). These results are in corroboration with the findings of Dhaka and Pareek (2008) who reported that the population increased gradually and reached to its peak in $32^{\text {nd }}$ and $33^{\text {rd }}$ week. But, these results are not in conformity with the findings of Selvaraj et al., (2011) they had reported the appearance of the leafhopper in $7^{\text {th }}$ standard week (February) and peak population in $10^{\text {th }}$ standard week (March). The observations were not in agreement with Laxman et al., (2013) and Arif et al., (2006) as they reported incidence of leafhopper was from first fortnight of July to first fortnight of February on both $B t$ and non- $B t$ with peak activity during November. The results of Nagar et al., (2017) were not agreement with present observations as they showed maximum population of leafhopper in $38^{\text {th }}$ standard week. The finding of Chauhan et al., (2017) and Boda and Ilyas (2017) also not conformity with present results as they observed the peak population of leafhopper on $B t$-cotton in $40^{\text {th }}$ standard week. The observations were not agreement with Nimbalkar et al., (2017) as they found peak population of leafhopper in $41^{\text {th }}$ standard week. The differences may be due to different geographical location as the present studies were conducted in North India while other from different geographical location.

The present studies revealed non-significant difference of leafhopper population in $B t$ and non- $B t$ hybrids. These results are in conformity with the findings of Kumar and Stanley (2006) who had reported nonsignificant difference among the sucking pest population in the $B t$ and non- $B t$ crops.

Different environmental variables affected leafhopper population in different ways.
Leafhopper population was positively correlated with relative humidity and rainy days while negative correlation with temperature, wind speed and rainfall which corroborates the finding of Laxman et al., (2014) who reported positive correlation between jassid population and relative humidity however, it is contrary to the reports of Iqbal et al., (2010) and Ashfaq et al., (2010) who reported negative correlation of leafhopper population and relative humidity. Kalkal et al., (2015) also reported negative correlation between leafhopper population and rainfall. Boda and Ilyas (2017) found that leafhopper population was negatively correlated with morning and evening relative humidity and rainfall.

\section{References}

Anonymous (2015) Annual Report 2014-15. All India Coordinated Cotton Improvement Project (Indian Council of Agricultural Research), Central Institute for Cotton Research, Coimbatore641003.

Arif, M. J., Gogi, M. D., Mirja, M., Zia, K. and Hafeez, F. (2006) Impact of plant spacing and abiotic factors on population dynamics of sucking insect pests of cotton. Pakistan Journal of Biological Sciences, 9(7), 1364-1369.

Ashfaq, M., Ane, M. N., Zia, K., Nasreen, A. and Hasan, M. (2010) The correlation of abiotic factors and physico-morphic characteristics of (Bacillus thuringiensis) $B t$ transgenic cotton with whitefly, Bemisia tabaci (Homoptera: Aleyrodidae) and jassid, Amrasca devastans (Homoptera: Jassidae) populations. African Journal of Agricultural Research, 5(22), 31023107.

Bhat, M. G., Joshi, A. B. and Singh, M. (1986) Relative loss of seed cotton yield by jassid and bollworm in some cotton 
genotypes (Gossypium hirsutum L.). Indian Journal of Entomology, 46, 169173.

Boda, V. and Ilyas, M. (2017) Evaluation of new insecticides against sucking pests of $B t$ cotton. International journal of Plant, Animal and Environmental Sciences, 7(2), 66-72.

Chauhan, R. P., Vekaria, M. V., Chaudhary, H. K. and Chaudhary, N. J. (2017) Seasonal incidence of sucking pests and their natural enemies in $B t$ cotton. Journal of Entomology and Zoology Studies, 5(5), 1274-1282.

Dahiya, K. K., Kumar, D., And Chander, S. (2013) Influence of abiotic factors on leafhopper and whitefly population build up in $B t$ cotton hybrids. Indian Journal of Entomology, 75(3), 194-198.

Dhaka, S. R. and Pareek, B. L. (2008) Weather factors influencing population dynamics of major insect pests of cotton under semi-arid agro-ecosystem. Indian Journal of Entomology, 70(2), 157-163.

Dhaliwal, G. S., Singh, R. and Chillar, B. S. (2008) Essentials of Agricultural Entomology. Ludhiana: Kalyani Publishers. 451.

Dhawan, A. K., Sidhu, A. S. and Simwat, G. S. (1988) Assessment of avoidable losses in cotton (Gossypium hirsutum and $G$. arboreum) due to sucking pests and bollworms. Indian Journal of Agricultural Research, 58(4), 290-292.

Gahukar, R. T. (1997) Production and utilization of potential biological control agents- Cotton insect pest in India. Pestology, 21(8), 28-48.

Grover, A. and Pental, D. (2003) Breeding objectives and requirements for producing transgenics for major field crops of India. Current Science, 84 (3), 310-320.

Iqbal, J., Hasan, M., Ashfaq, M., Sahi, S. T. and Ali, A. (2010) Studies on correlation of Amrasca biguttula biguttula (Ishida) population with physio-morphic characters of okra, Abelmoschus esculentus (L.) Monech. Pakistan Journal of Zoology, 43(1), 141-146.

Javed, H., Khan, M. R. and Ahmed, M. (1992) Role of physio-chemical factors imparting resistance in cotton against some insect pests. Pakistan Entomology University of Agriculture. Faisalabad, 111.

Kalkal, D., Roshan Lal, Dahiya, K. K., Singh, M. and Kumar, A. (2015) Population dynamics of sucking pests of cotton and its correlation with abiotic factors. Indian Journal of Agricultural Research, 49(5), 432-436.

Kumar, K.R. and Stanley, S. (2006) Comparative efficacy of transgenic $B t$ and non- transgenic cotton against insect pest of cotton in Tamil Nadu, India. Resistant Pest Management Newsletter, 15, 38-43.

Laxman, P. Ch. Samatha, Ch. Sammaiah (2014) Study on infestation of sucking insect pests on $B t$ cotton and non $B t$ cotton fields in Warangal - Telangana. International Journal of Advanced Biological Research, 4(2), 172-177.

Laxman, P., Ch. Samantha and Ch. Sammaiah (2013) Sucking pests on $B t$ and non $B t$ cotton. Indian Journal of Entomology, 75(2), 167-179.

Nagar, J., Khinchi, S. K., Naga, B. L., Sharma, S. L., Hussain, A. and Sharma, A. (2017) Effect of abiotic factors on incidence of sucking insect pests and their major natural enemies of Okra. Journal of Entomology and zoology studies, 5(3), 887-890.

Nimbalkar, N. A., Bade, B. A., Kadam, M. B. and Lad, D. B. (2017) Effect of abiotic factors on seasonal incidence of leafhopper and bioefficacy of some newer insecticides and biopsticides against leafhoppers on Okra. 
International Journal of Pure and Applied Bioscience, 5(3), 1044-1049.

Radhika, P., Sudhakar, K., Reddy, B. S. and Mohiddin, S. B. (2006) Field evaluation of cotton genotype against Amrasca biguttula bigutulla. Journal of Cotton Research and Development, 20(1), 134134.
Selvaraj, S., Adiroubane, D. and Ramesh, V. (2011) Population Dynamics of Leafhopper, Amrasca devastans Distant in Cotton and its Relationship with Weather Parameters. Annals of Plant Protection Sciences, 19(1), 47-50.

\section{How to cite this article:}

Praveen Kumar, S.P. Yadav, Krishna Rolania, Sunita Yadav, Surender Singh and Vikas. 2018. Population Dynamics of Amrasca biguttula biguttula on Bt and Non Bt Cotton and Its Correlation with Abiotic Factors. Int.J.Curr.Microbiol.App.Sci. 7(09): 2927-2934. doi: https://doi.org/10.20546/ijcmas.2018.709.364 